Tobacco products which are used in a way other than smoking are known as smokeless tobacco. The most common smokeless tobaccos are chewing tobacco, naswar, snuff, snus, gutka, and topical tobacco paste. Any product which contains tobacco is not safe for human health. There are more than twenty-five compounds in smokeless tobacco which have cancer causing activity. Use of smokeless tobacco has been linked with risk of oral cancer. Smokeless tobacco contains tobacco-specific nitrosamines (TSNAs), polonium, formaldehyde, cadmium, lead, and benzo[a]pyrene, which are carcinogenic agents. Although there is presence of some compounds, $\mathrm{Ca}$ rotenoids and phenolic compounds, that have cancer inhibiting properties, they are in low concentrations. Dry snuff use is linked with higher relative risks, while the use of other smokeless tobacco is of intermediate risk. Moist snuff and chewing tobacco have a very low risk for oral cancer. Therefore, from this review article, it was concluded that smokeless tobacco has risk for oral cancer - either low, medium or high depending on the balance between cancer causing agents and cancer inhibiting agents.

Key words: smokeless tobacco, oral cancer, TSNAs.

Contemp Oncol (Pozn) 2014; 18 (3): 160-164 DOI: $10.5114 /$ wo.2014.40524

\section{Risk for oral cancer from smokeless tobacco}

\author{
Khalid Hussain Janbaz'1, M. Imran Qadir², Hibba Tul Basser², \\ Tanveer Hussain Bokhari ${ }^{3}$, Bashir Ahmad ${ }^{1}$
}

${ }^{1}$ Faculty of Pharmacy, Bahauddin Zakariya University, Multan, Pakistan

${ }^{2}$ College of Pharmacy, GC University, Faisalabad, Pakistan

${ }^{3}$ Department of Chemistry, GC University, Faisalabad, Pakistan

\section{Introduction}

Tobacco products which are used in a way other than smoking are called smokeless tobacco. The most common smokeless tobacco products are chewing tobacco, naswar, snuff, snus, gutka, and topical tobacco paste. Any product which contains tobacco is not safe for human health. There are more than twenty-five compounds in smokeless tobacco which have cancer causing activity. The most harmful compounds in smokeless tobacco are tobacco-specific nitrosamines (TSNAs) and their levels are directly related to the risk of cancer. Smokeless tobacco has nicotine as an important constituent that causes addiction [1, 2]. Smokeless tobacco-induced carcinogenesis is entirely negative in animal models. In fact, the description of smokeless tobacco as a carcinogen is based exclusively on epidemiologic studies in humans [3]. There is insufficient evidence available for the carcinogenicity of smokeless tobacco in animals [4]. This evaluation is restricted to smokeless tobacco as used in Western societies, largely within the United States and Sweden. Smokeless tobacco is certainly used by numerous cultures in many parts of the world, including the Middle East as well as the Indian continent. On the other hand, smokeless tobacco goods inside these countries are significantly dissimilar from the products used within the West. For instance, within India, smokeless tobacco making is performed by individual farmers plus small companies with modest control in excess of fermentation in addition to curing, which increases the levels of TSNAs [5]. In India, smokeless tobacco is not all the same, given that the tobacco is frequently adulterated [6]. Three different types of smokeless tobaccos - chewing tobacco, wet snuff, and dried out snuff - are used within the US, while in Sweden wet snuff is almost the only type of smokeless tobacco product used. All of these goods are detained inside the lips, more often than not among the buccal mucosa as well as gingiva. These products are distinctly different from each other with respect to the tobacco used, the procedures for their production, and the populations that use them. Smokeless tobacco type is a precondition towards an understanding of smokeless tobacco-linked oral cancer [7, 8].

Smokeless tobacco types include loose-leaf chewing tobacco, moist snuff, and dry snuff [9]. Loose-leaf chewing tobacco is made from plants grown in Pennsylvania and Wisconsin; the leaves are air-cured, crushed into pieces and sweet flavoring agents are added. The use was originated by men in the US, mainly in combination with outdoor activities, the tobacco juices being spat out. There is decreased popularity of this product; use of it has slowly decreased by about 35\% over the past 15 years [10]. Fire- and air-cured dark tobaccos are used for moist snuff. The most well-liked type of smokeless tobacco in the US is moist snuff; it has become more popular by about $77 \%$ in the last 15 years [10]. Moist snuff is also called "snus". Conventional users of moist snuff put a 'pinch' of very crushed tobacco between the gingival and buccal mucosa. It is difficult to keep in place for a person, due to esthetically displeasing resultant movement. 

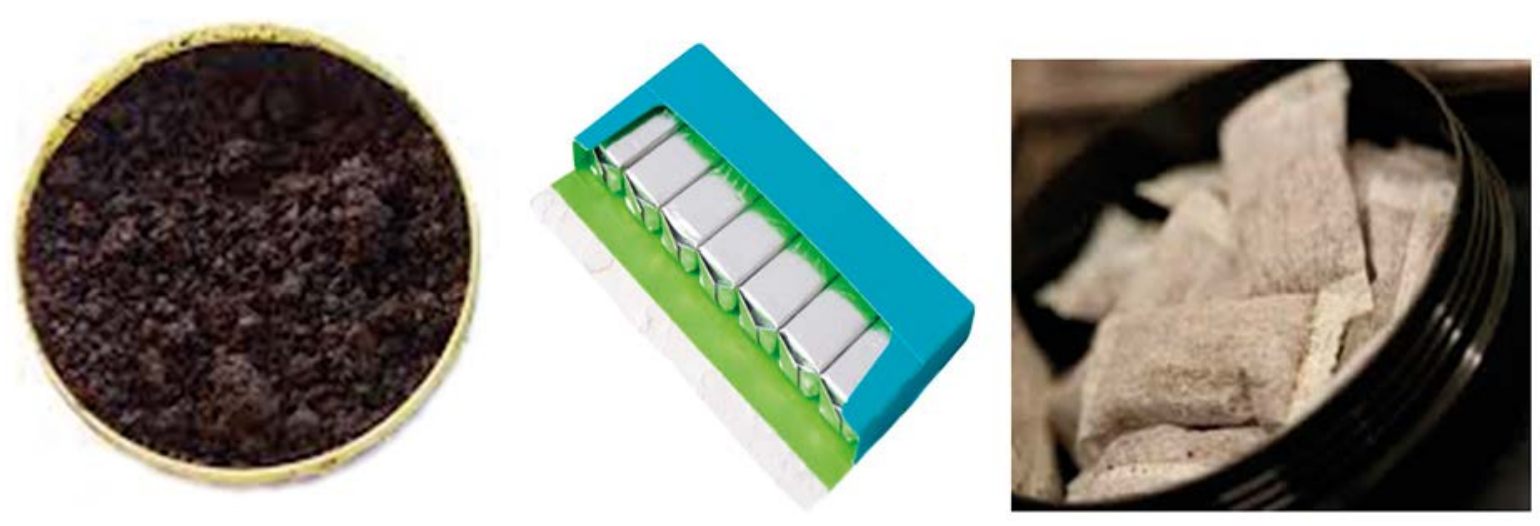

Fig. 1. Smokeless tobacco

Small, pre-portioned pouches similar to tea-bags are now used for sale of the modern moist snuff products. In the mouth these products remain fixed and produce very little juice. There is no need to spit them out and they can be used carefully. American and Swedish moist snuff products are manufactured in different ways. The fermentation process is used in traditional American products, providing specific flavors but leading to high concentrations of unnecessary by-products that are bacterially mediated, particularly TSNAs and nitrite. In Sweden during manufacturing heat is provided to moist snuff to pasteurize it and make a sterile product. Fermented, fire-cured tobacco is used for dry snuff that is subjected to powder, and originally was used through nasal inhalation. Dry snuff as an oral form of tobacco has been used by women in the southern US since the early 1800s [11, 12]. There is a decline in this type of use and sales have decreased by about $60 \%$ in the past 15 years [10].

\section{Cancer causing agents}

\section{Tobacco-specific $N$-nitrosamines}

Long-term use of some products having smokeless tobacco show increased risk of oral cancer and mainly this elevated risk is due to the presence of tobacco-specific $\mathrm{N}$-nitrosamines (TSNAs). N-nitrosonornicotine (NNN), 4-methyl-N-nitrosamino-1-(3-pyridyl)-1-butanone (NNK), N-nitrosoanatabine (NAT), and $N$-nitrosoanabasine (NAB) are the four principal compounds. Green tobacco has low levels of TSNAs, but during curing has high levels $[13,14]$. N-nitrosoanatabine, NAB, and NNN are synthesized from nor-nicotine, anabasine, and anatabine, respectively. $N$-nitrosonornicotine can also be produced from nicotine, whereas NNK is produced only from one precursor, nicotine.

Over the past decade the factors favoring the synthesis of TSNAs have been observed [13]. To reduce TSNAs, manufacturers and leaf growers use numerous strategies. Research includes the formation of tobacco cultivars having low levels of alkaloids, with special importance to stop the development of NNN and nor-nicotine $[13,14]$. The removal of nitrate-reducing microbial activity inhibits the development of TSNAs, whereas the action of other microbes gives an attractive essence. Careful temperature and humidity control conditions during curing also cause a reduction in TSNA concentration. For traditional cured

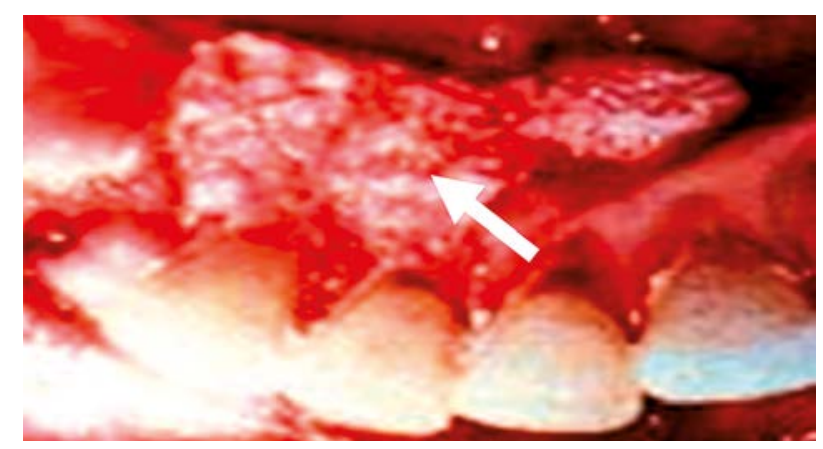

Fig. 2. Arrow showing oral cancer caused by smokeless tobacco in the oral cavity

tobacco, the replacement of heat exchange methods also causes a lower level of nitrosamine [15].

4-methyl-N-nitrosamino-1-(3-pyridyl)-1-butanone and NNN are the two TSNAs which are major cancer causing agents in smokeless tobacco. The International Agency for Research on Cancer (IARC) classified them as carcinogenic to humans $[16,17]$. Carcinogenicity is not related to NAB and NAT, according to IARC $[18,19]$.

\section{Cadmium}

In most soils, cadmium has a low concentration [20, 21], and in food it causes extensive spread of heavy metals [22]. The International Agency for Research on Cancer considered cadmium as a cancer causing agent due to increased cancer of lungs in industrial workers through inhalation of high concentrations of it or animal research [21]. A routine diet contains cadmium. Maximum percentage of total intake is provided by cereals and grains. Shellfish and some vegetables, such as spinach, also contain cadmium [22]. About $25 \mathrm{~g}$ of cadmium daily is supplied by a routine diet. $52 \mathrm{~g}$ daily cadmium intake is recommended by the Codex Alimentarius Commission of the $\mathrm{WHO}[23,24]$.

\section{Polonium}

Polonium-210 is a radioactive decay product of radium-226 [25]. It is present in the environment from rain or other weather events. Polonium-210 is not properly classified by IARC [26]. It is deposited in plants through surface absorption and then moves into edible parts such 
as seeds and fruits. The major source of polonium-210 is food ingestion. One to 10 picocuries ( $\mathrm{pCi}$ ) daily is supplied by the diet. In tobacco it originates from fertilizers [24, 27].

\section{Formaldehyde}

Formaldehyde is used widely in industry as a chemical and in manufacturing [28]. The International Agency for Research on Cancer classified it as a cancer causing agent in humans, basically in workers who work in industry and are continuously exposed to it or in animal research. Two to $3 \mathrm{mg} / \mathrm{l}$ concentration of formaldehyde is present endogenously in human blood and when exposed to the substance present in air its concentration changes [29]. Up to $6 \mathrm{ng} / \mathrm{g}$ is present in meat and poultry, 6 to $14 \mathrm{ng} / \mathrm{g}$ in fish, 2 to $26 \mathrm{ng} / \mathrm{g}$ in fruits and vegetables [30, 31].

\section{Polycyclic aromatic hydrocarbons}

Incomplete combustion of organic compounds produces polycyclic aromatic hydrocarbons (PAHs). Since the advent of fire they have been present in the environment and human diet, especially in meat [32]. Benzo[a]pyrene (BaP) is the most common and intensively studied PAH; IARC classified it in Group 2A as a cancer causing agent [33]. Sources of BaP are plants due to surface contamination and charcoal cooked meat [34, 35]. Low levels of about 0.1 to $4 \mathrm{ng} / \mathrm{g}$ of BaP were present in some brands of moist snuff, while some contained up to $63 \mathrm{ng} / \mathrm{g}$. Smokeless tobacco contains BaP mainly from fire-curing [24], and thus its concentration depends on the amount of tobacco used that is fire cured.

\section{Lead}

Based on animal research, IARC classified lead as a cancer causing agent to humans [36]. It appears in the environment through combustion of lead-containing fuels [37]. Absorption from dietary sources is limited, because lead in the soil is not readily taken up by most plants. In addition, lead in livestock is largely deposited in bone tissue, which limits its transfer to meat consumers. The main sources of dietary lead are fruits and vegetables; about $50 \mathrm{~g}$ per day is supplied by the diet, and a $150 \mathrm{~g}$ daily intake is set by the Codex Alimentarius Commission [23, 24].

\section{Cancer inhibiting agents}

There are two classes of agents that have the property to inhibit cancer among all the chemical components in smokeless tobacco leaf.

\section{Carotenoids}

The first class is the carotenoids, which include neoxanthin, violaxanthin, lutein, and carotene, present in tobac-

Table 1. Relative risk of oral cancer by using smokeless tobacco

$\begin{array}{lc}\text { Tobacco } & \text { Relative risk } \\ \text { moist snuff and chewing tobacco } & \text { very low risk } \\ \text { dry snuff } & \text { higher risk } \\ \text { other smokeless tobacco } & \text { intermediate risk }\end{array}$

co in higher concentrations [38]. Experimental evidence shows that carotene has the properties to inhibit the production of cancerous lesions $[39,40]$.

\section{Phenolic compounds}

Phenolic compounds are the second class which contains the greater anti-oxidant constituents in tobacco [9]. Fascinatingly, at both the initiation and the promotion stage of the lung tumor genesis by NNK, polyphenols exert an inhibitory effect [41-43]. As shown earlier, NNK is one of the important TSNAs.

\section{Risk for oral cancer}

Earlier epidemiological studies showed that the risk of oral cancer from smokeless tobacco was minimal. However, evidence from the experiment is controversial. For example, tumor formation is a result of chronic application of purified TSNAs to the oral mucous membrane [44]. Among tobacco products, there is significant variation in their cancer-producing activity. The characteristics of products are changed by the methods of processing (temperature variations, fermentation), and curing (flue curing, smoke curing or air curing) plays an important role [39, 45, 46]. Finally, the addition of preservatives and flavoring agents influences the anti-oxidant activity of tobacco products. Combustion of the smokeless tobacco causes the synthesis of a chemical mixture containing a highly reactive oxygen and smokers show low plasma levels of antioxidant vitamins, e.g. tocopherols, and ascorbic acid [47].

Regarding the management for oral cancer, the problem of resistance and tolerance to the existing drugs has led to decreased efficacy of these drugs. There have been attempts to overcome this problem by increasing the drug delivery to the target site by the use of polymers [48, 49] or through nanotechnology [50,51], and synthesis of new drugs, either by the use of proteomics [52] or synthesis from lactic acid bacteria [53] or marine microorganisms [54]. Large numbers of drugs are constantly being invented for their possible pharmacological value, particularly for their anti-inflammatory [55], hypotensive [56], hepatoprotective [57], hypoglycemic [58, 59], amoebicidal, antifertility, cytotoxic, antibiotic [60], spasmolytic [61], antimusculoskeletal pain [62], bronchodilator, antioxidant, anti-diarrheal, anti-epileptic [63], anti-Parkinsonism [64] and anti-Alzheimer [65] properties. Similarly, as cancer is the major cause of death in humans, new drugs and methods [66-85] are being investigated for management of cancers.

In conclusion, tobacco-specific $\mathrm{N}$-nitrosamines are the major cancer causing agents in smokeless tobacco. Others cancer causing agents that are present in smokeless tobacco include cadmium, polonium-210, formaldehyde, benzo(a)pyrene and lead. Although there is presence of some compounds, carotenoids and phenolic compounds, that have cancer inhibiting properties, they are in low concentrations. Therefore, it is concluded that smokeless tobacco has risk for oral cancer - either low, medium or high depending on the balance between cancer causing agents and cancer inhibiting agents. 
The authors are thankful to Mr. Akhtar Syed, English teacher in Sandal College, Faisalabad.

The authors declare no conflict of interests.

\section{References}

1. International Agency for Research on Cancer (2007). Smokeless Tobacco and Some Tobacco-SpecificN-Nitrosamines. Lyon, France: World Health Organization International Agency for Research on Cancer; IARC Monographs on the Evaluation of Carcinogenic Risks to Humans. Vol. 89.

2. Grasso P, Mann AH. Smokeless tobacco and oral cancer: an as sessment of evidence derived from laboratory animals. Food Chem Toxicol 1998; 36: 1015-29.

3. IARC monographs on the evaluation of carcinogenic risks to hu mans. Tobacco products, smokeless. Suppl 7. IARC Monographs, Lyon, France 1987; 357.

4. Brunnemann KD, Genoble L, Hoffmann D. N-nitrosamines in chewing tobacco: an international comparison. J Agric Food Chem 1985 33: 1178-81.

5. Muir CS, Zaridze DG. Smokeless tobacco and cancer. An overview. Vol. 74. IARC Scientific Publications, Lyon, France 1986; 35-44.

6. Hirayama T. An epidemiological study of oral and pharyngeal cancer in Central and South-East Asia. Bull World Health Organ 1966; 34: 41-69.

7. Jayant K, Balakrishnan V, Sanghvi LD, Jussawalla DJ. Quantification of the role of smoking and chewing tobacco in oral, pharyngeal and oesophageal cancers. Br J Cancer 1977; 35: 232-4.

8. Wahlberg I, Ringberger T. Smokeless tobacco. In: Tobacco: production, chemistry and technology. Davis DL, Nielsen MT (ed.). Blackwell Science, Oxford 1999; 452-60.

9. Federal Trade Commission (2001). Report to Congress for the years 1998 and 1999.

10. Rogozinski J. Smokeless tobacco in the Western world. Praeger Publishers, New York 1990; 42-4.

11. McGuirt WF, Wray A. Oral carcinoma and smokeless tobacco use: a clinical profile. In: Smokeless tobacco or health: an international perspective. US Department of Health and Human Services, NIH Publication 1993; No. 93-3461; 91-5.

12. Bush LP, Cui M, Shi H, et al. Formation of tobacco-specific nitrosamines in air-cured tobacco. Rec Adv Tobacco Sci 2001; 27: 23-46.

13. Peele DM, Riddick MG, Edwards ME, Gentry JS, Nestor TB. Formation of tobacco-specific nitrosamines in flue-cured tobacco. Rec Adv Tobacco Sci 2001; 27: 3-12.

14. Shi H, Fannin FF, Burton HR, Bush LP. Factors affecting nicotine to nornicotine conversion in burley tobacco (abstract). Tobacco Chem Res Conf 2000; 54: 27.

15. IARC monographs on the evaluation of carcinogenic risks to humans. 4-(methylnitrosamino)-1(3-pyridyl)-1-butanone (NNK). Vol. 37. IARC Monographs, Lyon, France 1985; 209.

16. IARC monographs on the evaluation of carcinogenic risks to humans. N-nitrosonornicotine (NNN). Vol. 37. IARC Monographs, Lyon, France 1985; 241.

17. IARC monographs on the evaluation of carcinogenic risks to humans. N-nitrosoanabasine (NAB). Vol. 37. IARC Monographs, Lyon, France $1985 ; 225$.

18. IARC monographs on the evaluation of carcinogenic risks to humans. N-nitrosoanatabine (NAT). Vol. 37. IARC Monographs, Lyon, France 1985; 233.

19. Texas A\&M University (2003). Don't be a dip - ingredients. Available at: http://dontdip.tamu.edu/quitting/anotherreasonquit.Htm.

20. IARC monographs on the evaluation of carcinogenic risks to humans. Cadmium and cadmium compounds. Vol. 58. IARC Monographs, Lyon, France 1993; 119.

21. Mahaffey KR, Corneliussen PE, Jelinek CF, Fiorino JA. Heavy metal exposure from foods. Environ Health Perspect 1975; 12: 63-9.

22. World Health Organization Codex Alimentarius Commission. Draft maximum levels for lead. CX/FAC 99/19. Rome, Italy 1998.
23. Hoffmann D, Adams JD, Lisk D, Fisenne I, Brunnemann KD. Toxic and carcinogenic agents in dry and moist snuff. J Natl Cancer Inst 1987; 79: 1281-6.

24. Watson AP. Polonium-210 and lead-210 in food and tobacco products: transfer parameters and normal exposure and dose. Nuclear Safety 1985; 26: 179-91.

25. IARC monographs on the evaluation of carcinogenic risks to humans. Some internally deposited radionuclides. IARC Monographs, Lyon, France 2001.

26. Samuelsson C. Medical consequences of polonium in snuff. Lakartidningen 1989; 86: 2290-1.

27. IARC monographs on re-evaluation of carcinogenic risks to humans. Formaldehyde. Vol. 88. IARC monographs, Lyon, France 2004.

28. IARC monographs on the evaluation of carcinogenic risks to humans. Formaldehyde. Vol. 62. IARC Monographs, Lyon, France $1995 ; 217$.

29. Möhler K, Denbsky G. Determination of formaldehyde in foods. Zeitschrift für Lebensmittel-Untersuchung und Forschung 1970; 142: 109-20.

30. Tsuchiya K, Hayashi Y, Onodera M, Hasegawa T. Toxicity of formaldehyde in experimental animals - concentrations of the chemical in the elution from dishes of formaldehyde resin in some vegetables. Keio J Med 1975; 24: 19-37.

31. Lijinsky $W$. The formation and occurrence of polynuclear aromatic hydrocarbons associated with food. Mutat Res 1991; 259: 251-61.

32. IARC monographs on the evaluation of carcinogenic risks to humans. Benzo(a)pyrene. Vol. 32. IARC Monographs, Lyon, France 1983; 211.

33. Zedeck MS. Polycyclic aromatic hydrocarbons: a review. J Environ Pathol Toxicol 1980; 3: 537-67.

34. Verschueren K. Handbook of environmental data on organic chemicals. $2^{\text {nd }}$ ed. Van Nostrand Reinhold Company, New York 1983.

35. IARC monographs on the evaluation of carcinogenic risks to humans. Lead and lead compounds: lead and inorganic lead compounds, organolead compounds. Vol. 87. IARC Monographs, Lyon, France 2004 a (in prep.).

36. Sanstead HH, Allaway WH, Burau RG, Fulkerson W, Laitinen HA, Newberne PM. Cadmium, zinc and lead. In: Geochemistry and the environment. Vol. I. The relation of selected trace elements to health and disease. National Academy of Sciences, Washington, DC 1974.

37. Hecht SS, Rivenson A, Braley J, DiBello J, Adams JD, Hoffmann D. Induction of oral cavity tumors in F344 rats by tobacco-specific nitrosamines and snuff. Cancer Res 1986; 46: 4162-6.

38. Garewal H. Antioxidants in oral cancer prevention. Am J Clin Nutr 1995; 62: 1401S-6S.

39. Garewal HS, Katz RV, Meyskens F, et al. Beta-carotene produces sustained remissions in patients with oral leukoplakia: results of a multicenter prospective trial. Arch Otolaryngol Head Neck Surg 1999; 125: 1305-10.

40. Chung FL, Morse MA, Eklind KI, Xu Y. Inhibition of tobacco-specific nitrosamine-induced lung tumorigenesis by compounds derived from cruciferous vegetables and green tea. Ann NY Acad Sci 1993; 686: 186-201.

41. Yang CS, Yang GY, Landau JM, Kim S, Liao J. Tea and tea polyphenols inhibit cell hyperproliferation, lung tumorigenesis, and tumor progression. Exp Lung Res 1998; 24: 629-39.

42. Cao G, Verdon CP, Wu AH, Wang H, Prior RL. Automated assay of oxygen radical absorbance capacity with the COBAS FARA II. Clin Chem 1995; 41: 1738-44.

43. Ou B, Huang D, Hampsch-Woodill M, Flanagan JA, Deemer EK. Analysis of antioxidant activities of common vegetables employing oxygen radical absorbance capacity (ORAC) and ferric reducing antioxidant power (FRAP) assays: a comparative study. J Agric Food Chem 2002; 50: 3122-8.

44. Leffingwell JC. Leaf chemistry. In: Tobacco: production, chemistry and technology. Davis DL, Nielsen MT (eds.). Blackwell Science Ltd., Oxford 1999.

45. Li Q, Krauss M, Maher M, Bokelman G, Gadani F. Reduction of tobacco specific nitrosamines (TSNAs) by increasing endogenous antioxidants in burley tobaccos: a review of results from field experiments. CROBM 2003; 15: 252. 
46. Stegmayr B, Johansson I, Huhtasaari F, Moser U, Asplund K. Use of smokeless tobacco and cigarettes - effects on plasma levels of antioxidant vitamins. Int J Vitam Nutr Res 1993; 63: 195-200.

47. Traber MG, van der Vliet A, Reznick AZ, Cross CE. Tobacco-related diseases. Is there a role for antioxidant micronutrient supplementation? Clin Chest Med 2000; 21: 173-87.

48. Khalid SH, Qadir MI, Massud A, Ali M, Rasool MH. Effect of degree of cross-linking on swelling and drug release behaviour of poly(methyl methacrylate-co-itaconic acid) [P(MMA/IA)] hydrogels for site specific drug delivery. J Drug Delvr Sci Tech 2009; 19: 413-8.

49. Hussain A, Khalid SH, Qadir MI, et al. Water uptake and drug release behaviour of methyl methacrylate-co-itaconic acid [P(MMA) IA)] hydrogels cross-linked with methylene bis-acrylamide. J Drug Delvr Sci Tech 2011; 21: 249-55.

50. Naz S, Qadir MI, Ali M, Janbaz KH. Nanotechnology for imaging and drug delivery in cancer. J Chem Soc Pak 2012; 34: 107-11.

51. Ehsan O, Qadir MI, Malik SA, Abbassi WS, Ahmad B. Efficacy of nanogold-insulin as a hypoglycemic agent. J Chem Soc Pak 2012; 34: 365-70.

52. Qadir MI. Qadirvirtide. PakJ Pharm Sci 2011; 24: 593-5.

53. Masood MI, Qadir MI, Shirazi JH, Khan IU. Beneficial effects of lactic acid bacteria on human beings. Crit Rev Microbiol 2011; 37: 91-8.

54. Javed F, Qadir MI, Janbaz KH, Ali M. Novel drugs from marine microorganisms. Crit Rev Microbiol 2011; 37: 245-9.

55. Oadir MI. Medicinal and cosmetological importance of Aloe vera. Int J Nat Ther 2009; 2: 21-6.

56. Qadir MI. Medicinal values of ginger. Int J Nat Ther 2010; 3: 19-22.

57. Ahmad M, Mahmood Q, Gulzar K, Akhtar MS, Saleem M, Qadir MI. Antihyperlipidaemic and hepatoprotective activity of Dodonaea viscosa leaves extracts in alloxan-induced diabetic rabbits (Oryctolagus cuniculus). Pak Vet J 2012; 32: 50-4.

58. Qadir MI, Nisa TU, Malik SA. Effect of Eugenia jambolana leaves extracts on blood glucose levels of experimental diabetic rabbits. Pharmacologyonline 2009; 3: 829-35.

59. Qadir MI, Malik SA. Anti-diabetic activity of inorganic metals Eugenia jambolana Lam. (Myrtaceae) flowers. Pharmacologyonline 2010; 2: 979-85.

60. Amin N, Qadir MI, Khan TJ, Abbas G, Ahmad B, Janbaz KH, Ali M. Antibacterial activity of Vacuum liquid chromatography (VLC) isolated fractions of chloroform extracts of seeds of Achyranthes aspera. J Chem Soc Pak 2012; 34: 589-92.

61. Janbaz KH, Nisar U, Ashraf M, Qadir MI. Spasmolytic, bronchodilator and antioxidant activities of Erythrina superosa Roxb. Acta Pol Pharm 2012; 69: 1111-7.

62. Qadir MI, Qureshi U. Musculoskeletal pain treated by bisphosphonate therapy. Inorganic Chem Indian J 2010; 5: 2-6.

63. Oadir MI, Nian H. A review on epilepsy and seizure. Int J Med Res 2010; 1: 26-32.

64. Janbaz KH, Qadir MI, Younas F, Ali M, Malik SA. Future strategies in treatment of parkinson's disease. J Col Med Sci (Nepal) 2011; 7: 67-71.

65. Saleem A, Qadir MI. Future strategies in treatment of Alzheimer's disease. Rev Pharmacol 2011; 4: 226-30

66. Ameen S, Oadir MI, Ahmad B. Pharmacogenomic approaches in the treatment of breast cancer by tamoxifen. Pak J Pharm Sci 2012; 25: 469-76.

67. Ilayas M, Qadir MI. Role of estrogen in breast cancer. Rev Pharmacol 2010; 2: 48-52.

68. Tabasum A, Qadir MI. Deficiency of vitamin K linked to cancer, osteoporosis and heart diseases. Int I Pharm Rev Res 2010; 1: 24-32.

69. Qadir MI. A cheap method for diagnosis of cancer. Pharmacologyonline 2010; 3: 186-9.

70. Niaz M, Qadir MI, Niaz M. Tumor markers for early detection of cancer. Pharmacologyonline 2010; 3: 628-33.

71. Akash MS, Khan IU, Shah SN, Asghar S, Massud A, Oadir MI, Akbar A. Sustained release hydrophilic matrices based on xanthan gum and hydroxypropyl methylcellulose: development, optimization, in vitro and in vivo evaluation. J App Pharm 2010; 4: 89-103.

72. Oadir MI, Mirza F. Prevention of gastric cancer by Helicobacter pylori eradication: a review. Pharmacologyonline 2010; 3: 92-100.

73. Qadir MI. An introduction to antibiotic production. Pharmacologyonline 2010; 3: 151-4.
74. Oadir MI, Malik SA. Comparison of alterations in red blood cell count and alterations in hemoglobin concentration in patients suffering from rectal carcinoma undergoing 5-fluorouracil and folic acid therapy. Pharmacologyonline 2010; 3: 240-3.

75. Akhtar T, Qadir MI. Advances in management of non-small cell lung cancer. Rev Pharmacol 2011; 4: 233-41.

76. Mehvish S, Qadir MI. Gene therapy for hepatocellular carcinoma. Rev Gene Therapy 2011; 1: 11-21.

77. Khalid M, Qadir MI. Suicide gene therapy. Rev Gene Therapy 2011; 1: $36-42$.

78. Qasim S, Saleem U, Ahmad B, Aziz MT, Qadir MI, Mahmood S, Shahzad K. Therapeutic efficacy and pharmacoeconomics evaulation of pamidronate versus zoledronic acid in multiple myeloma patients. J App Pharm 2011; 4: 438-52.

79. Rajoka MI, Qadir MI, Pervaiz N, Ibrahim Z, Bukhari SA, Ahmad B. Nutrigenomics and its approaches for control of chronic diseases. Curr Biotechnol 2012; 1: 258-65.

80. Yousuf A, Qadir MI, Bashir A. Recent advances in treatment of ovarian cancer. Pharmacologyonline 2012; 3: 1-7.

81. Qadir MI. Advances in treatment of lungs cancer. Independ Rev 2011; 103: 176-80.

82. Janbaz KH, Qadir MI, Sidiq Z. Stages, alcoholism and genetic basis of breast cancer. Acad Res Int 2011; 1: 383-5.

83. Qadir MI, Malik SA, Naveed AK, Ahmad I. Plasma lipid profile in sarcoma patients. Pak J Pharm Sci 2006; 19: 155-8.

84. Oadir MI, Naveed AK, Ahmad I, Malik SA. Plasma lipid profile in childhood non-Hodgkin lymphoma patients. Pak Paed J 2007; 31: 167-70.

85. Farooqi AA, Butt G, Yousaf G, et al. Making personalized prostate cancer medicine a reality: challenges and opportunities in the re-establishment of gold standards. Pak J Pharm Sci 2013; 26: 831-40.

\section{Address for correspondence}

\section{Imran Oadir}

College of Pharmacy, GC University

Faisalabad, Pakistan

e-mail: mrimranqadir@hotmail.com

Submitted: 27.08 .2013

Accepted: 13.11 .2013 